\title{
PARTICIPATION IN CONTRACT FISHING IN A DEVELOPING ECONOMY: A QUALITATIVE RESPONSE MODEL ANALYSIS
}

\author{
Namso N. Frank, PhD \\ Akwa Ibom Agric. Devt. Programme \\ Uyo, Akwa Ibom State, Nigeria \\ email: franknamso2@yahoo.com \\ Gabriel S. Umoh, PhD \\ Dept. of Agricultural Economics \& Extension \\ University of Uyo, Uyo, Nigeria \\ email: gsumoh@hotmail.com
}

\begin{abstract}
Many fishermen in developing countries are resource poor and rely on a number of avenues to obtain production inputs. One of such ways is contract. This study examined determinants of contract fishing participation in Akwa Ibom State, Nigeria. Data were collected from 91 contracted artisanal fishers for analysis. Multinomial logit model was used to examine the determinants of their participation in contract fishing. Results show that participation in contract fishing was determined by the level of education, household size, number of productive assets; income, extension contact and group membership. However, age, years of fishing experience and credits were found to have negative effects on participation.
\end{abstract}

\section{KEY WORDS}

Fishing; Social group; Production; Credits.

The fishery sector in Nigeria is dominated by artisanal fishermen. Artisanal fishing involves fishing using "relatively" small amount of capital and energy, small fishing boats, making short fishing trips close to shore and producing mainly for local consumption (FAO, 2007). Estimate shows that $85 \%$ of the fish domestic supply is catered for by artisanal fishermen. A total of 260,000 metric tons $(\mathrm{mt})$ come from the coastal waters and $200,000 \mathrm{mt}$ from inland waters, $11 \%$ of annual production comes from industrial fishing and only $4 \%$ from aquaculture (Federal Department of Fisheries, 2005).

In recognition of the importance of fisheries to the Nigerian economy, many policies and programmes have been put in place. They includes the establishment of the Department of Fisheries by the colonial Government, the Sea fisheries decrees (No. 30) of 1971 which focused on controlling (fish inspectorate and quality assurance) and regulating (sea licensing) coastal fisheries, the Exclusive Economic Zone (EEZ) decree of 1978. Institutional reforms aimed at fishery development included, Agricultural Development Projects (ADPs) established in 1975, the National Council on Agriculture (NCA) formed and charged to work with Federal Department of Fisheries to implement fisheries policies, the National Institute of Marine Research (NIOMR) and National Institute for Fresh Water Fisheries Research (NIFFR) both established to provide support, policy advice and some extension services in fisheries, the National Accelerated Fish Production Programme (NAFPP) mandated to supply fishing inputs to fishermen at a $50 \%$ subsidy to increase maximum capture efficiency, the Fish Development Project of Directorate for Food, Roads and Rural Infrastructure (DFRRI). However, the first comprehensive agricultural policy for Nigeria with fisheries as a component was put forward in 1988. The document decentralized the responsibilities to the three tiers of Government in Nigeria - Federal, State and Local Governments.

International assistance for fisheries development has also been received by Nigeria. Food and Agricultural Organisation (FAO) and; United Nations Development Programme (UNDP) have funded many community-based artisanal fisheries projects in Nigeria (Ovie and Raji, 2006). Government and indeed International Agencies interventions in the fishery sub sector are informed by several factors: firstly, the fishery sub-sector has been unable to meet with the nutritional and industrial demand for fish and fish products. 
Estimates by Frank (2014) put the mean National production of fish at 384,913 metric tons per annum while mean aggregate demand is 1,321,802 metric tons leaving a demandsupply gap of about $936,889.2$ metric tons per annum and an annual per capita consumptions rate of $7.5 \mathrm{~kg}$. This shortfall is augmented with fish import estimated to range between $700,000-900,000$ metric tons, annually and at a cost of some $\$ 400$ million (FDF, 2005). Not only is this a huge drain on the financial resources of the country, but the nutritional level of the people is also adversely affected. Secondly, the artisanal fishermen who produce the bulk of the product are still relatively subsistent, highly versatile with low income outlay, poor fish distribution net-work, poor processing methods, high post-harvest losses of (35-40\%) and an incredible adverse demographic/socio-economic and environmental situation (Tobor, 1990). In fact, according Udoh and Nyienakuna, (2008) they are among the most socially disadvantaged groups in the country, as a result of the remoteness of their habitations, which is conditioned by the location of the resources. According to FAO (2005) artisanal fish landings, depends more on the socio- economic conditions of production, including availability and cost of credit, than on the remarkably stable state of fish resources. These socio- economic conditions of production is aptly described by Nwosu (2004), as the economic plight of the people - vicious web of low productivity, income and capital investments. The foremost of the subsistence economic plight is the low capital based as well as inaccessibility to investment funds. Funding of artisanal fish production according to Udo and Nyienakuna, (2008) is one major constraint to increase fish production in Nigeria. Ben-Yami (2000) captured it thus: "credit is needed for today's fuel, food as well as for equipment, be it a small net, an outboard engine or a new boat". This situation has caused many responses and the private sector is not an exception.

The private sector has also responded to the failure of the fisheries sector to meet the demand of the National economy. One important private sector intervention is through contract arrangements involving the private investor as the "principal" and the artisanal fishermen as the "agent". The principal-Agent contract arrangement has also been viewed as a response to various kinds of market imperfections and credited for timely provision of inputs and production services, credit provision, introduction of new technology and new skills, risk reduction as well as access to new markets (Eaton and Shepherd, 2001). Whereas, Acemoglu, (1999) described contract as a mechanism designed to resolve the trade-off between incentive and insurance; Eaton and Shepherd, (2001) viewed it as a response to various kinds of market imperfections with the basic motives of incentive alignment.

Studies on the determinants of participation in agricultural contracts; however the econometric estimation of these determinants had not yielded uniform direction of impact of significant factors influencing participation or non-participation. Constales, Son, Lapar, and Tioncgo (2008) using multinomial logit model identified the factors that determined the likelihood of engagement in formal or informal contracts to be the level of the farmer's education, main occupation, membership of cooperative society, the benefits the households obtain from engaging in contracts, the opportunities and constraints they face in engaging in contract farming, their capacities to comply with the requirement of such agreements and lastly the requirements that integrators of market intermediaries impose on farmers. A contrary empirical result was reported by Birthal, Joshi, and Gulati (2005) from his study of determinants of participation in contract. His logit analysis of participation in contract farming schemes indicated that farm size and education were not significant predictors, implying that small farmers were not excluded from contracting. Similarly, Anim (2011) employed the probit model and reported that access to usable information, farmers training (transfer of knowledge and skill on crops), mono- farming system, extension visits, membership of farm organization and income increases the probability of participation in contract farming. However, remittances (having an alternative source of funds) and post-harvest loses were negatively associated with contract farming. The plausible explanation was that farmers with alternative source of finance and those pruned to high post-harvest losses were not likely to participate in contract farming. D'silva, Hayrol, Jegak, Bahaman, (2009) reported that knowledge, attitude, involvement in agricultural activities, experience and age had influence 
on perception and played a crucial role in agricultural development and acceptance of contract farming. Frick, Birkenholzi, Garderner, and Matchmes, (1995) corroborated this fact and defined knowledge as organized or processed information. Attitude was also found to influence acceptance of contract farming. Those with negative attitude towards agriculture were unlikely to accept contract farming. Similar study by Kumar, (2007) confirms that, more farmers in India opted for contract farming due to positive attitude and the need for price protection on their crops. Elepu and Nalukenge (2009), in a study of contract farming, the case of sorghum, sunflower and rice in Uganda reported that the determinants of farmer's participation in contract farming were reliable/assured market, high output prices, access to critical inputs, and presence of extension services and reduction of production risks. This finding corroborates Setboonsarng, (2008) studies, who reported that contract farming evolution was sequel to market and institutional failure. Cai, Ung, Setboonsarng and Leung (2008) reported that younger household heads, with more education, less assets value, larger family size and who live closer to the highway were more likely to participation in contract farming. Gender, age, province, distance to the market, own land etc. were not found to be significant determinants of participation in contract farming.

Other empirical works on determinants of contract participation by livestock farmers include: Knoeber and Thurman (1995); Martin, (1997); Parcel and Langemeir, (1997). All these Authors in their respective write up upon hog and broilers industry cases argued that risk reduction is a major incentive for participating in contract farming. Other factors that could contribute to improving effectiveness of the contract included timely procurement, higher premium, soil and water testing, crop insurance, improved inputs, timely payments, prior price information, more crops coverage, direct purchase from farm, collective payment of bonus and produce price, better extension, and transparency in grading system (Singh, 2006).

Observations reveal that in the fishery contract arrangements exists in the fishery sector in developing countries such as Nigeria. However, as important as this practice is in bridging input demand - supply gaps, it is yet to receive sufficient attention in empirical literature. A few exploratory studies in Nigeria Adams (2001), Inakan (2002) and Okon (2003) confirmed the existence of contract fishing. Nonetheless, empirical information on this economic activity remains at the preliminary stage. This research is not only to bridge this existing gap in knowledge and literature on artisanal contract fishing but also to unveil those factors that make fishermen engage in this arrangement. The study is based on assumption that there are certain factors that determined participation in contract fishing, and that economic theories should be able to explain them for a better understanding of the contractual arrangements.

The main objective of the study was to analyze the effect of contract fishing on the performance of the fishermen in Akwa Ibom State of Nigeria using econometric model. The specific objectives were to: Analyse the socio-demographic characteristics of the artisanal fishermen in Akwa Ibom State and, determinants of fishermen's participation in contract fishing in Akwa lbom State.

\section{THEORETICAL FRAMEWORK}

Qualitative Response model (QRM): Qualitative response model is a family of regression models in which the regressand is qualitative in nature. This is different from those regression models which the regressand, the dependent variable or the response variable is quantitative. In qualitative response model, the dependent variable is binary or dichotomous, usually taking a yes or no decision. Thus, the response variable or regressand can only take one or two values, say 1 and o. (Gujarati and sargeseter, 2007). In this study the decision on whether or not to participate in project or take up new technology is considered under the general framework of utility. It is assumed that economic agents, including farmers participate in project only when a perceived utility or net benefit from participation is greater than the counterfactual i.e. without participation. This is because the cardinal objective of every rational farmer is to maximize profit or utility. Although utility is not 
directly observed, the action of farmers is observed in the choice they make. Suppose that $Z_{a}$ and $Z_{b}$ represent a farmer's utility for two choices, which are denoted by $Y_{a}$ and $Y_{b}$ respectively. The linear random utility model could then be specified as:

$$
Y_{a}=\beta_{a} X_{i}+\epsilon_{a} \text { and } Y_{b}=\beta_{b} X_{i}+\epsilon_{b}
$$

where $Y_{a}$ and $Y_{b}$ denote perceived utilities of participation or non-participation respectively, $X_{i}$ is the vector of exogenous variables that affect the perceived desirability of the project, $\beta_{a}$ and $\beta_{\mathrm{b}}$ are parameter estimates of exogenous variables, and $\epsilon_{\mathrm{a}}$ and $\epsilon_{\mathrm{b}}$ are disturbance terms assumed to be independently and randomly distributed (Greene, 2003).

In the case of participation in contract fishing, if a fisherman decides to participate, it follows that the perceived utility or net benefit from participation is greater than the utility or net benefit from non participation depicted as:

$$
Y_{i a}\left(\beta_{a} X_{i}+\epsilon_{a}\right)>Y_{i b}\left(\beta_{b} X_{i}+\epsilon_{b}\right),
$$

The probability that a fisherman will participate in contract could then be defined as:

$$
\begin{aligned}
& P(Z=1 / X)=P\left(Y_{i a}>Y_{i b}\right) \ldots \\
& P\left(\beta_{a} X_{i}+\epsilon_{a}-\beta_{b} X_{i}-\epsilon_{b}\right)>0 / X ; \\
& P\left(\beta_{a} X_{i}-\beta_{b} X_{i}+\epsilon_{a}-\epsilon_{b}\right)>0 / X ; \\
& P\left(X / / X_{i}+\epsilon\right)>0 / X=f\left(\beta_{a} X_{i}\right) .
\end{aligned}
$$

Where $P$ is a probability function, $Y_{i a}, Y_{i b}$ and $X_{i}$ are as defined above, $\epsilon=\epsilon_{a}-\epsilon_{b}$ is a random error term, $\beta_{a}=\left(\beta_{a}-\beta_{b}\right)$ is a vector of unknown parameter estimates that can be interpreted as a net influence of the vector of explanatory variables influencing participation, and $f\left(\beta_{a} X_{i}\right)$ is a cumulative distribution function of $\in$ evaluated at $\beta_{a} X_{i}$. The exact distribution of $f$ depends on the distribution of the random disturbance term $\in$. Depending on the assumed distribution that the random disturbance term follows, several qualitative choice models can be estimated (Greene, 1997). The Multinomial Logit (MNL) model was used to model participation in contract fishing of fishermen involving discrete dependent variables with alternative choices. The advantage of the MNL is that it permits the analysis of decisions across more than two categories, allowing the determination of choice probabilities for different categories and is most appropriate when variables are unordered (Madalla, 1983; Eboh, 2009).

\section{STUDY AREA}

This study was carried out in Akwa Ibom State, Nigeria. The State is located at latitude $4^{\circ} 33$ and $5^{\circ} 33$ North and longitude $7^{\circ} 35$ and $8^{\circ} 25$ East. By land mass, it is the tenth largest State in Nigeria with an area of 8,412 square kilometer. It has a population of 3.92 million (National Population Commission, 2006) with an average population density of 350 people per square kilometre. The State is one of the core States in the Niger Delta region located in the South-South geo-political zone in Nigeria. It has the largest wetland in West Africa and the longest coastland in Nigeria which spans over 129km (IFAD-CBNRMP Report (2005). The State is drained by three main rivers - Imo, Qua and Cross river. The Akwa Ibom coastline is dotted with many fishing communities (of variable sizes according to the number of fishing units (canoes) and number of fishermen.) Within this fishing communities are some coastal settlements (ine) with a significant concentration of artisanal fisherfolks.

Multi-stage sampling technique was used in selecting samples for the study. First, six coastal Local Government Areas (LGAs) were purposively selected. The selection was based on the commercial fishing status of the LGAs and the intensity of fishing activities. Information on the fishing intensity in the Local Government Areas (LGAs) were obtained from and Moses, (1990), FAO, (2005) and reconnaissance survey. The Local Government 
Areas are; Ibeno, Ikot Abasi, Itu, Mbo, Oron and Uruan. Secondly, sample frame of fishing settlements in each selected LGA was collected from the Fishery Department of the State Ministry of Agriculture. From the sample frame, five (5) fishing settlements were randomly selected from each selected coastal Local Government Areas. The last stage of sampling was the random selection of four fishermen each from the selected five fishing settlements. One hundred and twenty (120) questionnaires were administered, out of which 91 were retrieved, giving a response rate of $76 \%$. The 91 were used for the analysis.

Primary data was used for the analysis. The relevant primary data were obtained through survey of the study area. Primary data of interest were type and terms of contract models engaged by the artisanal fishermen, inputs utilized, output of fishermen, sales value, labour supply, number of crews, assets acquired, boat size, years of experience etc.

\section{METHODS OF DATA ANALYSIS}

The social and economic characteristics of respondents were analyzed using descriptive statistic. These included mean, proportions and percentages. Determinants of participation in contract fishing were analyzed using the multinomial logit model. The Multinomial Logit model is a qualitative response model. The model is as presented below:

$$
\begin{aligned}
& P_{i j}=\frac{e^{\beta j \alpha i}}{\sum_{k=j}} e^{\beta j \alpha i}
\end{aligned}
$$

Where, $P_{i j}$ is response Probability associated with participation in fishing contract, $i=1,2$ .......n variables; $k=0,1 \ldots . . j$ participation status $(j=0$ for non contract fishermen, $j=1$ for former (disengaged) contract fishermen and; $j=2$ for contract fishermen), contract fishermen participation was the reference category and $\beta j$ is vector of parameters that relates $\alpha_{i}$ 's to the probability of participation in contract fishing.

After appropriate normalization, the generalized model employed in the estimation was:

$$
\frac{P_{i j}}{1+\sum_{k=j}^{\beta j \alpha i}} e^{\beta j \alpha i}
$$

The variables used in the analysis were grouped into two namely: (1) Respondents general characteristics - Age (measured in years), marital status (dummy where $1=$ married, $0=$ not married), Fishermen educational level (number of years spent in formal school), household size (number of persons in fishing household), fishing experience (years spent in artisanal fishing). (2) Firm's characteristics - Firm's assets (Naira value of all productive fishing assets), Firm's income (Naira value of fishing income) and Firm's credit (Naira value of firm's credit). (3) Institutional factors - Extension training (Dummy where 1=Yes, $0=\mathrm{No}$ ), membership of social group (Dummy where $1=$ Yes, $0=$ No). Gretl programme software was used for the analysis.

Age. The distribution of the respondents by age shows that the average age of contract fishermen was found to be 40 years while the modal age of the contract fishers was 31 40years. This implies that those willing to source for fishing inputs through were younger men.

Sex. Analysis of the distribution of the fishermen by sex shows that all the contracted fishermen in the study area were males. This may due to the social construct built from the culture and norms of the study area and indeed Nigeria. Culturally, fishing is considered a male activity while the women are expected to play supportive role such as in fish processing and marketing.

Education. Result of analysis on educational level of the respondents in the study area shows that the modal educational group for contract fishers was primary level. This implies that the contracted fishers were illiterate. This must have engendered awareness and consequently informed their attitude towards credit pursuit. 
Table 1 - Socio - Demographic Characteristics of Artisanal Fishermen in Akwa Ibom State

\begin{tabular}{|c|c|c|}
\hline $\mathrm{S} / \mathrm{N}$ & Variables & Frequency Percentage \\
\hline 1 & $\begin{array}{l}\text { Age of Fisherman (years) } \\
21-30 \\
31-40 \\
41-50 \\
51-60 \\
61+ \\
\text { Total }\end{array}$ & $\begin{array}{l}40 \text { years } \\
11(12.09 \%) \\
41(45.05 \%) \\
29(31.87 \%) \\
10(10.99 \%) \\
0(0.00 \%) \\
91(100 \%) \\
\end{array}$ \\
\hline 2 & $\begin{array}{l}\text { Sex: } \\
\text { Male } \\
\text { Female }\end{array}$ & $\begin{array}{l}91(100 \%) \\
0\end{array}$ \\
\hline 3 & $\begin{array}{l}\text { Educational Level } \\
\text { No formal Education } \\
\text { Primary } \\
\text { Secondary } \\
\text { NCE/OND } \\
\text { Total }\end{array}$ & $\begin{array}{l}25(12.09 \%) \\
48(63.74 \%) \\
16(21.98 \%) \\
2(2.20 \%) \\
91(100 \%)\end{array}$ \\
\hline 4 & $\begin{array}{l}\text { Household size of Fishermen } \\
1-2 \\
3-4 \\
5-6 \\
7-8 \\
9+ \\
\text { Total }\end{array}$ & $\begin{array}{l}6 \text { Persons } \\
3(3.30 \%) \\
26(28.57 \%) \\
39(42.86 \%) \\
12(13.19 \%) \\
11(12.09 \%) \\
91(100 \%) \\
\end{array}$ \\
\hline 5 & $\begin{array}{l}\text { Fishing Experience (yrs) } \\
1-5 \\
6-10 \\
11-15 \\
16-20 \\
21+ \\
\text { Total }\end{array}$ & $\begin{array}{l}12 \text { years } \\
6(6.59 \%) \\
25(27.47 \%) \\
31(34.07 \%) \\
19(20.88 \%) \\
10(11.00 \%) \\
91(100 \%) \\
\end{array}$ \\
\hline 6 & $\begin{array}{l}\text { Marital Status of Fishermen } \\
\text { Single } \\
\text { Married } \\
\text { Separated } \\
\text { Total }\end{array}$ & $\begin{array}{l}3(3.3 \%) \\
81(89 \%) \\
7(7.7 \%) \\
91(100 \%)\end{array}$ \\
\hline 7 & $\begin{array}{l}\text { Source of Credit (Frequency) } \\
\text { Percentage credit from Bank } \\
\text { Percentage credit from Cooperatives Society } \\
\text { Percentage credit from Money Lenders } \\
\text { Percentage credit from Family Members } \\
\text { Percentage credit from Etibe (Contribution) } \\
\text { Percentage credit from Church }\end{array}$ & $\begin{array}{l}1(1.00 \%) \\
16(17.58 \%) \\
18(19.78 \%) \\
11(10.68 \%) \\
56(54.36 \%) \\
1(1.00 \%) \\
103(100 \%) \\
\end{array}$ \\
\hline 8 & $\begin{array}{l}\text { Crew's Remuneration } \\
\text { Flat Rate } \\
\text { Shared Wage } \\
\text { Total }\end{array}$ & $\begin{array}{l}77(84.61 \%) \\
14(15.85 \%) \\
91(100 \%)\end{array}$ \\
\hline
\end{tabular}

Household size. The result on the distribution of fishermen by household size shows that the modal household size for contract fishers was 5-6 persons. The average household size of contract fishers was 5 persons. This implies that the contracted fishers had large household size which translates into more household expenditure. This must have been one of the reasons for involvement in contract.

Fishing Experience. Result on years of fishing experience reveals that the average years of fishing experience of contract fishermen was 12 years. The modal years of fishing experience of the contract $(34.07 \%)$ was $11-15$ years. This implies that they were the contract fishermen were not novice in the art of fishing.

Marital Status. On the marital status of fishermen, the result shows that, $89 \%$ of the contract fishers in the study area were married. The implication is that majority of the contracted fishers in the study area were married men with wives and children whose labour are used in various fishing activities. 
Sources of Credit. The sources of credit available to the fishers in the study area shows that the most common source of credit for contract fishers was etibe. This implies that the contracted fishers depended more on their personal contribution for their up keep inspite of the available other sources of credit.

Crew's Remuneration. Crew's remuneration shows that the contracted fishers paid their crew member's flat wage. This may not be unconnected with the fact that most of the crew members were apprentice and only a weekly stipend was to be given to them for their upkeep.

\section{RESULT OF THE MULTINOMIAL LOGIT}

Result of the Multinomial Logit meant to identify the determinants of fishermen participation in contract fishing shows that contract fishing category is the reference category while former contract and non-contract categories are the determinants groups. The percentage of correct predictions calculated as the total number of correct predictions of the number of observations shows that the model correctly predicted $89.7 \%$ observations. The Likelihood test ratio (chi-squared value) was 369.88 with a significant probability (chi-square $>$ value $)=0.0000$.

Table 2 - Determinants of Contract fishing participation (Multinomial Logit)

\begin{tabular}{|c|c|c|c|c|}
\hline Former Contract & Coefficient & Std. Error & \multicolumn{2}{|c|}{$p$-value } \\
\hline Const & 8.60055 & 3.78757 & 2.2707 & 0.02316 \\
\hline Age_ & $-0.274303^{* * *}$ & 0.0747694 & -3.6687 & 0.00024 \\
\hline MS & -0.759863 & 0.821822 & -0.9246 & 0.35517 \\
\hline EDU & 0.830193 & 0.596531 & 1.3917 & 0.16401 \\
\hline HHS & $0.403064^{* *}$ & 0.162158 & 2.4856 & 0.01293 \\
\hline EXP & $-0.227498^{\star \star \star}$ & 0.0775196 & -2.9347 & 0.00334 \\
\hline ASSETS & $9.0675 \mathrm{e}-06^{\star * *}$ & $2.33228 e-06$ & 3.8878 & 0.00010 \\
\hline INCOME & $3.82079 \mathrm{e}-05^{\star \star}$ & $1.70748 e-05$ & 2.2377 & 0.02524 \\
\hline EXT & $1.67454^{\star * *}$ & 0.548676 & 3.0520 & 0.00227 \\
\hline GM & $1.03451^{*}$ & 0.611474 & 1.6918 & 0.09068 \\
\hline $\begin{array}{l}\text { CREDIT } \\
\text { Non Contract Fishing }\end{array}$ & $-2.29235 e-06^{*}$ & $1.26265 \mathrm{e}-06$ & -1.8155 & 0.06945 \\
\hline $\begin{array}{l}\text { Const } \\
\text { Age_}\end{array}$ & $\begin{array}{l}49.7199 \\
-0.99675^{\star \star \star}\end{array}$ & $\begin{array}{l}10.1772 \\
0.197968\end{array}$ & $\begin{array}{l}4.8854 \\
-5.0349\end{array}$ & $\begin{array}{l}<0.00001 \\
<0.00001\end{array}$ \\
\hline MS & 1.20804 & 1.37117 & 0.8810 & 0.37830 \\
\hline EDU & $2.18292^{*}$ & 1.19087 & 1.8330 & 0.06680 \\
\hline HHS & $0.497049^{*}$ & 0.259731 & 1.9137 & 0.05566 \\
\hline EXP & $-1.64952^{* \star \star}$ & 0.31986 & -5.1570 & $<0.00001$ \\
\hline ASSETS & $3.83935 e-06$ & $3.9721 \mathrm{e}-06$ & 0.9666 & 0.33376 \\
\hline INCOME & $0.000125621^{* * *}$ & $3.31542 \mathrm{e}-05$ & 3.7890 & 0.00015 \\
\hline EXT & $3.63037^{\star * *}$ & 1.11997 & 3.2415 & 0.00119 \\
\hline GM & $2.33031^{* *}$ & 1.27308 & 1.8305 & 0.06718 \\
\hline CREDIT & $-5.16559 e-06^{*}$ & $2.14103 e-06$ & -2.4127 & 0.01584 \\
\hline Mean dependent var & 1.051724 & S.D. dependent var & & \\
\hline Log-likelihood & -66.47723 & Akaike criterion & & \\
\hline Schwarz criterion & 252.7827 & Hannan-Quinn & & \\
\hline
\end{tabular}

Number of cases 'correctly predicted' $=208$ (89.7\%), Likelihood ratio test: Chi-square (20) = 369.877 [0.0000] ***, **, * significant at $1 \%, 5 \%$ and $10 \%$ level respectively.

Source: Extracted from computed print-out by the Author, 2014.

It was statistically significant at $1 \%$ and implies that the artisanal fishermen are heterogeneous and the explanatory variables are collectively significant in explaining the fishermen participation in contract fishing. To test the robustness of the model, choice-based 
sampling was applied, though the coefficients are not affected, the estimation errors are minimized with this procedure. Greene (2003) stated that this procedure adjusts the estimated asymptotic covariance matrix for possible misspecification in the model. The mean dependent var. is 1.051724 , S.D. dependent var. 0.861337, the log-likelihood is 66.47723 , Akaike criterion is 176.9545, Schwarz criterion is 252.7827 and Hannan-Quinn is 207.5352. The $p$-value is used to determine if the variable is significant. The $p$-value is adjust significance when the standard normal probability of $N[0,1]$ is greater than or equal to the ratio of the estimated variable to the variable's estimated standard error (Greene, 2003).

Age. Age in both the former contract and non-contract fisher's estimations is negatively significant at $1 \%$ level. It implies that the probability of being a former contract fisher or noncontract fisher relative to participating in contract fishing increases as fisher's age decreases. Therefore, age is found to be a strong determinant of participation in contract fishing in the study area.

Marital Status. Marital status (MS) showed no uniform coefficient sign. It is not a significant determination in both estimations even at $10 \%$ level. Thus, deserves no further attention.

Education. Education status of the fishermen has the expected positive apriori sign but is not a contract fishing participation determinant in the former contract fisher's computation. It is statistically significant at $10 \%$ level. The implication is that the probability of being in the non-contract group relative to participation in contract fishing increases as fisher's education level increases.

Household Size (HHS). Analysis of household size of the respondents as determinants of participation reveals that household size is significant at $5 \%$ for the former contract group and at $10 \%$ for the non-contract group. The sign is positive and is in line with the a priori expectation. It implies that the probability of being in former contract or non-contract fisher's group relative to participation in contract fishing increases with increase in fisher's household size.

Experience. Years of fishing experience of household heads estimation as a determinant of contract fishing participation is negatively significant at $1 \%$ level of probability in both the former and non-contract fisher's computations. It implies that the probability of being in former contract or non-contract fisher's group relative to participation in contract fishing increases with decrease in fisher's years of experience.

Assets. The econometric analysis of asset as a determinant of contract fishing participation in Akwa Ibom State proves positively significant in the former-contract estimation at $1 \%$ level while in the non-contract fisher's estimation, though it has the a priori expected sign, it is not significant. The implication is that, the probability of being in the former-contract fisher's group relative to participation in contract fishing increases with increase in fishermen's assets.

Income. Income has the positive expected a priori sign for both categories of fishermen. In the former-contract fisher's category estimation, it is statistically significant at $5 \%$ and at $1 \%$ level of probability in the non-contract category estimation. It implies that the probability of being in the former contract or non-contract fisher's group relative to participation in contract fishing increases with increase in fishermen assets. The finding shows that income is a very important determinant of contract fishing participation in the study area.

Extension Visits. Extension visit to fishermen as a dummy has proven a strong determinant of contract fishing participation. It is significant at $1 \%$ level of probability in both estimations with the expected positive a priori sign. It therefore implies that, the probability of being in the former-contract or non-contract fisher's group relative to participation in contract fishing increases with increase in the frequency of extension visits.

Group Membership. Group membership as a variable was found to positively determine contract fishing participation in both former contract and non-contract fisher's estimation at $10 \%$ and $5 \%$ level respectively. It is deduced that the probability of being in the former-contract or non-contract fisher's group relative to participation in contract fishing will 
increases as the artisanal fishermen increases their the frequency of groups/associations interactions.

Credit. Credit as a variable in the multinomial logit result is negatively significant in both categories estimation. For former-contract category, it is significant at $10 \%$ and for noncontract category; it is significant at $10 \%$ level of probability. The variable is negatively signed. The sign, though contrary to expectation, implies that the probability of being in the former contract or non-contract fisher's group relative to participation in contract fishing increases with decrease in fishermen's credit.

\section{CONCLUSION}

The study identified education, household size, number of assets; income, extension visit and group membership to have positive impact on contract fishing participation while negative determinants were age, experience and credit. Equally, it discovered that, as the educational status, assets, income, extension contacts and group membership of the fishing household appreciates, households tend to prefer contract fishing participation. In this respect, the study recommends raising the awareness of the fishermen on the importance of contract fishing as a quasi-formal credit arrangement and the adverse consequences of not having the right fishing gadgets for exploiting the full potentials of the Nigeria territorial waters. Government and extension agents can play pivotal roles in such campaigns.

\section{REFERENCES}

1. Acemoglu, D. (1999). Lecture Notes for Graduate Labour Economics. Massechusetts Institute of Technology, Camdridge. American Economic Review, (62):777-795.

2. Adams, M. J. (2001). Economics of contract and non contract Artisanal Fishery in Itu Local Government Area. Unpublished B.Sc. Project. University of Uyo, Uyo. Nigeria. pp. $1-43$.

3. Anim, F. D. K. (2011). Small-scale maize farmers' decision to participate in contract farming: Implications for integration into the marketing chain. African Journal of Business Management, 5(13): 65-79.

4. Ben-Yami, M. (2000). Integration of Traditional Institutions and People's Participation in Artisanal Fisheries Development Project in South Eastern Nigeria. FAO Corporate Document Repository, http//www.fao/org/dorcep /004/y1290e/y1290ede.htm.of 10/04/2013.

5. Birthal, P.S., Joshi, P. K. and Gulati, A. (2005). "Vertical Coordination in High Value Commodities: Implication for the Small Holders". International Food Policy Research Institute MTID Discussion paper No. 85, 87-95

6. Cai, J. L. Ung, S. Setboonsarng and P. Leung (2008). Rice Contract Farming in Cambodia: Empowering Farmers to Move beyond the Contract toward Independence. ADB Institute Discussion Paper No. 109: 65-79.

7. Constales, N. T., Son, M. L. Lapar, and M. Tioncgo (2008). Determinants of Participation in Contract Farming in Pig Production in Northern Viet Nam. Pro-poor Livestock Policy Initiative RRNR. 08-04, (2008) http:///www.Fao.Org/ag/pplpi.html 28/05/2011

8. D'silva, J. L, Hayrol, A. M. S, Jegak, U, Bahaman, A. S. (2009) A Review of Contract Farming and Factors that Impinge Youths Acceptance of Contract Farming European Journal of Social Sciences, 11(2): 318-323

9. Eaton C, and Shepherd, A. W. (2001) Contract Farming: Partnership for Growth. FAO Services Bulletin 145. http://www.fao/dorcep/004/y0937e09. html. 28/05/2010

10. Eboh, E. C. (2009). Social and Economic Research: Principles and Methods. $2^{\text {nd }}$ Edition. Enugu: African Institute for Applied Economics, Enugu, Nigeria. pp 89-96

11. Elepu, G. and Nalukenge, I. (2009) Contract Farming Smallholders and Commercialization of Agriculture in Uganda: The Cases of Sorghum, Sunflower, and Rice Contract Farming Schemes. pp 56-71 
12. Food and Agricultural Organisation (FAO) (2007) "Nigeria: Country profile. Country Profiles .http//www.fao.org/fi/website/FIRetrieveAction.do?= countrysector \&xml=FI-CPNG.xm /\& lang=en

13. Federal Department of Fisheries (FDF), (2005). Report of Presidential Committee on Fisheries and Aquaculture Development. Consolidated Report of Federal Department of Fisheries, Federal Ministry of Agriculture and Rural Development. Abuja.(1):13-25

14. Federal Ministry of Agriculture (1988). Agricultural Policy for Nigeria, Federal Ministry of Agriculture, Abuja.

15. Frank, N. N. (2014). Contract Fishing and the performance of Artisanal Fishermen in Akwa lbom State, Nigeria - A Comparative Analysis. An Unpublished PhD Thesis. Faculty of Agriculture, University of Uyo, Nigeria. pp 45-56

16. Frick, M. J., Birkenholzi R. J., Garderner, H. and Matchmes, K. (1995) "Rural and Urban Innercity High School Student Knowledge and perception of Agriculture", Journal of Agriculture Education, (36): 1-9.

17. Greene, W. H. (2003). Econometric Analysis. $5^{\mathrm{TH}}$ Edition. New Jersey: Prentice Hall. Englewood Cliffs, New Jersey.pp 23-35

18. Gujarati, G. N. and Sargeetha (2007). Basic Econometric. Tata McGraw Hill Publishing Company, Limited, New Delhi. pp231-241

19. Guo, H., Jolly, R. W. and Zhu, J. (2005). Contract farming in China or ball and chain. Paper presented at $15^{\text {th }}$ Annual World Food and Agric-business Symposium. IAMA in Chicago, June 25-26, 2005, pp 46-56.

20. Inakan, A. S. (2002). Economic of contract and non contract Artisanal Fishery in Ikot Abasi Local

21. Government Area. Unpublished B.Sc. Thesis. University of Uyo, Uyo. pp. 11-32.

22. Knoeber, C; Thurman, W. (1995). Don't Count Your Chickens..." Risk And Risk Shifting in the Broiler Industry. American Journal of Agricultural Economics, (77): 486-496.

23. Kumar, P. (2007) "Resources Provision, productivity and contract farming: A case study of Punjab, Paper Presented at ICAR-NCAP and USAID, New Delhi. pp 21-35

24. Maddala, G. S. (1983). Limited Dependent and Qualitative Variables in Economics. Cambridge: Cambridge University Press. pp 89-106

25. Martins, L; (1997). Production Contract, Risk Shifting and Relative Performance Payments in the Pork Industry Journal Agricultural Applied Economic, 29(2): 267-278.

26. Moses, B. S. (1990) Akwa Ibom Agricultural Development Project (AKADEP). Studies and Proposals for the Development of Akwa Ibom State Fisheries.No. 14: 23-50

27. NPC, (2007). The 2006 Population Census Official Gazette (Extraordinary), 24(94), National Population Commission Report.

28. Nwosu, A. C. (2004). Private Sector Initiatives in the Agricultural Sector, in Enhancing Private Sector-led Growth in Nigeria. In: Proceedings of the $13^{\text {th }}$ Annual Conference of the Regional Research Unit. Benin City, Nigeria 8-12 ${ }^{\text {th }}$ November. pp. 97-112.

29. Okon, I. E. (2003). An Empirical Analysis of Artisanal Contract Fishing in Itu Local Government

30. Area, Akwa Ibom State. An Unpublished B.Sc. Project. University of Uyo. Nigeria. pp. 145.

31. Ovie, S. I and Raji, A. (2006) Food Security and Poverty Alleviation through Improved valuation and Governance of River Fisheries in Africa. National Institute for Freshwater Fisheries Research Paper. New Bussa, Nigeria. pp 3-8

32. Parcell, J., Langemeier, M., (1997). Feeder Pig Producers and Finishers: Who Should Contract? Canadian Journal of Agricultural Economics, 45: 317-327.

33. Setboonsarng, S. (2008). Global Partnership in Poverty Reduction: Contract Farming and Regional Cooperation. ADB Institute Discussion Paper No 89 http://www.adbi.org/discussion-paper/2008/02/25/249/global partnership, poverty reduction.

34. Singh, S. (2006), "Contract Farming for Agricultural Development: Review Theory and Practice with Special Reference to India”, CENTAD Working Paper No. 2, An Oxfam GB Initiative, New Delhi. pp 215-253 
35. Tobor, J. G. (1990) The Fishing Industry in Nigeria status and Potential for Self Sufficiency. In Sanni, A. O. and Onimisi, H. U. (2009) Capacity Building and Training Requirement for Effective Fisheries in Nigeria- A Review. Nature and Science 7(4): 8789.

36. Udoh, A. J. and Nyienakuna, M. G. (2008). Examining Socio-Economic Characteristics and Adoption Trend of Artisanal Fishers of Akwa lbom State in West Africa. Journal of Agriculture and Social - Sciences, 4: 141-146. 